\title{
UVODNIK
}

\section{RESOLUCIJA 1325 IN VLOGA VIDIKA SPOLA}

V mednarodnem prostoru je v zadnjem času opazno vse bolj intenzivno dogajanje v povezavi z uresničevanjem Resolucije Varnostnega sveta Organizacije združenih narodov 1325 in $\mathrm{z}$ njo povezanih resolucij. Iz leta $\mathrm{v}$ leto je organiziranih več mednarodnih dogodkov na temo žensk, miru in varnosti, razvijajo se programi izobraževanj in usposabljanj ter konceptualni okviri vidika spola, oblikujejo se tudi sistemske rešitve, tako $\mathrm{v}$ mednarodnih organizacijah kot v nacionalnih strukturah. Med takšnimi sta imenovanje ambasadorjev za ženske, mir in varnost ter uvajanje svetovalcev za vidik spola. Generalštab Slovenske vojske je v preteklem letu ustanovil delovno mesto svetovalca za to področje. Kot strokovna nosilka za področje vidika spola v SV sem vesela, da je bil prepoznan pomen agende o ženskah, miru in varnosti ter da smo z angažiranjem strokovnjakov in ob podpori vodilnih uspeli izdati publikacijo na akademsko-strokovni ravni. Hvaležna sem za prispevke sodelavcev iz mednarodnega prostora, ki so se odzvali povabilu in delijo z nami svoje poglede, rešitve in izkušnje. To je namreč bistvena vrednost te publikacije: deliti pomeni skrbeti (sharing is caring). Izbira tem ponuja uresničevanje resolucije in vidika spola od mednarodne ravni prek nacionalnih rešitev do uresničevanja v MOM. Čeprav je resolucija obširno razložena v prispevkih avtorjev, želim za bolj celostno razumevanje uvodoma z vami deliti še nekaj ključnih povezovalnih dejavnikov med resolucijo in vidikom spola. Pri tem izhajam iz konceptualnih rešitev mednarodnih organizacij ter svoje vključitve v Natov odbor za vidike spola, kar omogoča širjenje obzorij, razvoj stroke, sproža nova razmišljanja v iskanju rešitev in prenos idej v delovanje SV.

Resolucija 1325 pomeni mejnik v vlogi žensk pri preprečevanju in reševanju spopadov, mirovnih procesih, humanitarnem odzivu ter pokonfliktni obnovi. Govori o treh med seboj povezanih dejavnikih: ženskah, miru in varnosti. Ni varnosti brez miru in ni miru brez varnega okolja. Prav tako ni miru in varnosti brez vključitve celotne 
populacije v obravnavo. V preteklosti so bile namreč ženske pogosto izključene iz mirovnih procesov. Vključitev pretežno le enega vidika vodi do spoznanja, da bodo tako verjetno sprejete delne rešitve.

V 15 letih od sprejetja resolucije 1325 so dogajanja ob naraščajočih asimetričnih grožnjah v kompleksnem varnostnem okolju pripeljala do potrebe po celovitejših pristopih zagotavljanja varnosti in miru v svetu. O številnih dejstvih, ki so bila v preteklosti prezrta, se je v mednarodnem prostoru v tem času začelo resno razpravljati pri iskanju rešitev. Oboroženi spopad in obdobje po njem imata drugačen vpliv na ženske kot na moške, poleg tega sta delovanje moških in žensk v takšnih razmerah lahko različna ali pa tudi enaka, vendar v družbi različno sprejeta zaradi družbeno pogojenih zaznav. Lahko bi poudarili, da v zvezi s tem ne govorimo o biološko določenem spolu, ki je podan ob rojstvu, temveč o družbeno pogojenih značilnostih med spoloma, ki so oblikovane v neki družbi in kulturi ter določajo vloge med spoloma. Spol se tako izraža v naši realnosti, na primer: medtem ko je v oboroženem spopadu večina moških rekrutiranih za opravljanje bojnih nalog, ženske z otroki ostajajo doma ali pa so se prisiljene preseliti. Zato predstavljajo tudi večino notranje razseljenih oseb in beguncev, tako na begunski poti kot v begunskih centrih. Pri tem je njihova varnost izpostavljena, pogosto so tarča skupin bojevnikov, ugrabljene, zasužnjene ali zlorabljene. Dejstvo je tudi, da so deklice in dečki drugače izpostavljeni, bodisi deklice za prezgodnje in prisilne poroke bodisi dečki za zgodnje rekrutiranje v bojevniške vrste. Pri splošnem prepoznavanju vlog moških in žensk v oboroženem spopadu ter po njem največkrat prevladuje misel o ženskah kot žrtvah in moških kot bojevnikih. Resnica je, da so tudi ženske bojevnice in močni akterji za mir ter moški žrtve namerno povzročenih dejanj. Pereč problem v sodobnih konfliktih pomeni tudi na spolu temelječe nasilje, ki je še vedno prisotno v prevelikem obsegu. Predvsem se izvaja nad ženskami, pa tudi deklicami in dečki ter moškimi, bodisi kot oblika trpinčenja bodisi kot sredstvo taktike bojevanja.

Lahko bi rekli, da se je vidik spola v povezavi z MOM po eni strani razvil zaradi uresničevanja resolucije 1325 ter po drugi iz izkušenj vojsk. Težišče vidika spola v MOM je usmerjeno v vključitev družbeno pogojenih vlog žensk in moških, deklic in dečkov v procese operacije. Pri tem je treba upoštevati različne varnostne situacije, s katerimi se posamezniki soočajo glede na njihov spol. Kot že povedano, se ženske, moški, deklice in dečki srečujejo z različnimi varnostnimi tveganji zaradi družbeno in kulturno oblikovanih zaznav o vlogah žensk in moških v neki družbi. Prepoznavanje in razumevanje čim bolj celostne situacije o varnostnih razmerah pomeni orodje za doseganje večje operativne učinkovitosti. Na izvedbo operacije na primer vpliva tudi prepoznavanje poti žensk, ki so običajno drugačne od poti, ki jih uporabljajo moški, saj imajo drugačne opravke. Izkazalo se je, da takšne informacije vplivajo na zagotavljanje varnosti, zaščito lastnih sil in uspešnost operacije. Zato je vključevanje vidika spola v vseh procesih na vseh ravneh ter v vseh fazah delovanja bistveno, celostne informacije o dogajanju na območju delovanja pa prispevajo k odločitvam poveljujočih. Izkušnje iz MOM so pripeljale tudi do spoznanj o nekaterih omejitvah pri opravljanju nalog, predvsem na taktični ravni, na primer pri vključevanju lokalnih 
žensk, še posebno na tistih območjih delovanja, na katerih ženskam ni dovoljeno v javnosti komunicirati z neznanimi moškimi, v sestavi vojaških sil pa so bili pretežno moški. Vključevanje vidika spola v opravljanje nalog je postalo nujnost, na katero opozarjajo tudi mednarodne organizacije, kot so OZN, Nato, EU in druge.

Sodobne vojske potrebujejo v svoji sestavi tako pripadnice kot pripadnike na vseh ravneh in na različnih dolžnostih. To velja tako za opravljanje nalog v MOM kot tudi za opravljanje nalog v domačem okolju. Mednarodne organizacije vse bolj poudarjajo vključevanje žensk v vse strukture, a se v vojskah pogosto še vedno porajajo vprašanja na to temo - predvsem v smislu enakosti spolov, telesne pripravljenosti žensk in opuščanja omejitev opravljanja nekaterih dolžnosti za ženske. Vse večja je težnja uresničevanja načela enakosti spolov, pri čemer pa v vojaških vrstah lahko nastane nevarnost enačenja enakosti z istostjo. Dojemanje enakosti kot istosti lahko vodi v enostranske ali preveč posplošene rešitve. Pomisleki, da bi upoštevanje na primer anatomsko in fiziološko pogojenih razlik med moškimi in ženskami pri oblikovanju standardov pomenilo nižanje meril in slabšo učinkovitost, vodijo k pomembnejšemu vprašanju: Ali so standardi v resnici oblikovani po zahtevah posameznih dolžnosti ali pa so preveč splošni in predvsem, ali so oblikovani tudi na podlagi vključitve vidika spola. Bistveno je razumeti, da različne naloge zahtevajo različne kompetence in pripravljenost posameznika. Resnica je, da moški in ženske ne bodo nikoli isti. Med spoloma obstaja raznolikost, ki bi morala biti prepoznana kot prednost in ne kot slabost. Brez vključitve obojih celovitosti ni mogoče doseči, saj vključitev moškega in ženskega pogleda na isto zadevo prinese celovitost s spajanjem različnosti.

Spreminjajoče se varnostne razmere pred vse nas postavljajo nove izzive in zahtevajo še tesnejše povezovanje organizacij tako na nacionalni kot mednarodni ravni, da bomo zagotovili celovite in učinkovite rešitve. Vremenski pojavi z obsežnimi posledicami uničenja vse pogosteje zahtevajo vključevanje vojsk v naloge zaščite in reševanja. Lanske razmere z množičnimi migracijami z vojnih žarišč, Bližnjega vzhoda ter iz Afrike v Evropo so zahtevale tudi vključitev vojsk v izvedbo nalog na domačih tleh. Podobno kot med opravljanjem nalog v MOM so se vojske in druge vladne ter nevladne organizacije, vključene $\mathrm{v}$ obravnavo beguncev in migrantov, srečale z različnimi kulturami, pri čemer imajo družbeno pogojene vloge med moškimi in ženskami velik pomen. Te razmere odpirajo nadaljnja spoznanja o vključevanju vidika spola $\mathrm{v}$ nove smeri. Temeljno dejstvo, da družbo tvorimo tako ženske kot moški, deklice in dečki, ostaja, prav tako kot raznolikost, ki naj nas s celovitostjo vodi v zagotavljanje varnosti in miru.

Želim vam prijetno branje avtorskih del v nadaljevanju in upam, da bo širilo nova obzorja ter sprožilo nova razmišljanja. 